\title{
Prospective Mapping of Schistosomian Risk by Markovian Modelling and Multi-criteria Analysis in Central Côte d'Ivoire
}

\author{
Gnahoua Guy Roger Gnazalé, Adonis Krou Damien Kouamé, and Valère-Carin Jofack Sokeng
}

\begin{abstract}
The Bélier region and the autonomous district of Yamoussoukro, is a region of central Côte d'Ivoire that records every year cases of schistosomiasis contamination. Although the figures are low, this area is of interest for epidemiological control. The schistosomiasis infection with schistosoma haematobium or urinary bilharziasis is the most widespread and is important in some areas along the main rivers of the region. The development of maps of areas at risk schistosomiasis by 2027 by Markov modeling using Markov chains observable and by combining layers of sensitivity and vulnerability of 2027 of the infection show a change in the surface risk of contamination from $17 \%$ in 2017 to $23 \%$ in 2027 of the total area of the region. These areas are mainly located in the departments of Yamoussoukro, Toumodi and Djékanou. 15\% of the localities in this region are high-risk areas in 2017 and $23 \%$ in 2027 . The prediction of risk areas and localities at high risk of contamination by Markov modeling makes any preventive control strategy possible
\end{abstract}

Keywords - Bélier, Mapping, markov, multicriteria analysis, schistosomiasis risk, Yamoussoukro (Côte d'Ivoire).

\section{INTRODUCTION}

Schistosomiasis or bilharzia is a water-dependent disease caused by trematodes of the genus Schistosoma. It occurs mainly in two forms: intestinal and urogenital [1]-[3]. It is widespread in the world, especially in sub-Saharan Africa [4]. In 2018, 95.3 million people worldwide received chemoprevention against schistosomiasis including 76.2 million school-aged children and 19.1 million adults [1]. Studies carried out on the Ivorian territory report the presence of this parasitosis in several localities of the country [5]-[12]. The results of parasitological surveys conducted in the Yamoussoukro Autonomous District and in the Bélier region to identify areas at high risk of contamination indicate the presence of schistosomiasis caused by schistosoma haematobium or urinary bilharzia in the departments of this region. Although the prevalence rate of this part of Côte d'Ivoire in 2017 is regressing and estimated at $0.3 \%$ according to the Direction de l'Informatique et de l'Information Sanitaire (DIIS) of the Ministry of Health and Public Hygiene, it still remains a high-risk region for schistosomiasis contamination. The aim of this article is to model the risk of contamination by 2027 based on the trends

Submitted on October 27, 2021.

Published on December 20, 2021.

G. G. Roger Gnazalé, Virtual University of Côte d'Ivoire, Côte d'Ivoire. (e-mail: gnahoua.gnazale@uvci.edu.ci)

A. K. Damien Kouamé, Center of Research and Remote Sensing Application (CURAT) / Félix Houphouët Boigny University, Abidjan, Côte d'Ivoire.

(e-mail: adonisdamien ${ }^{\circledR}$ yahoo.fr) determined in 2007 and 2017 using a Markovian approach and a multicriteria analysis.

\section{DAtA, MATERIALS AND Methodologies}

\section{A. Geographic Setting}

The Bélier region and the Autonomous District of Yamoussoukro, formerly known as the Lakes region, are located in the centre of Côte d'Ivoire (Fig. 1). Precisely between $6^{\circ} 24^{\prime} 00^{\prime \prime}$ and $7^{\circ} 24^{\prime} 15^{\prime \prime}$ North latitude and $4^{\circ} 33^{\prime} 00^{\prime \prime}$ and $5^{\circ} 33^{\prime} 30^{\prime \prime}$ West longitude. The Autonomous District of Yamoussoukro is a special territorial entity with a legal personality and financial autonomy covering an area of 3500 square kilometres. The Bélier region has an area of 5,344 $\mathrm{km}^{2}$, i.e., $2.08 \%$ of the national territory and is an integral part of the "V Baoulé".

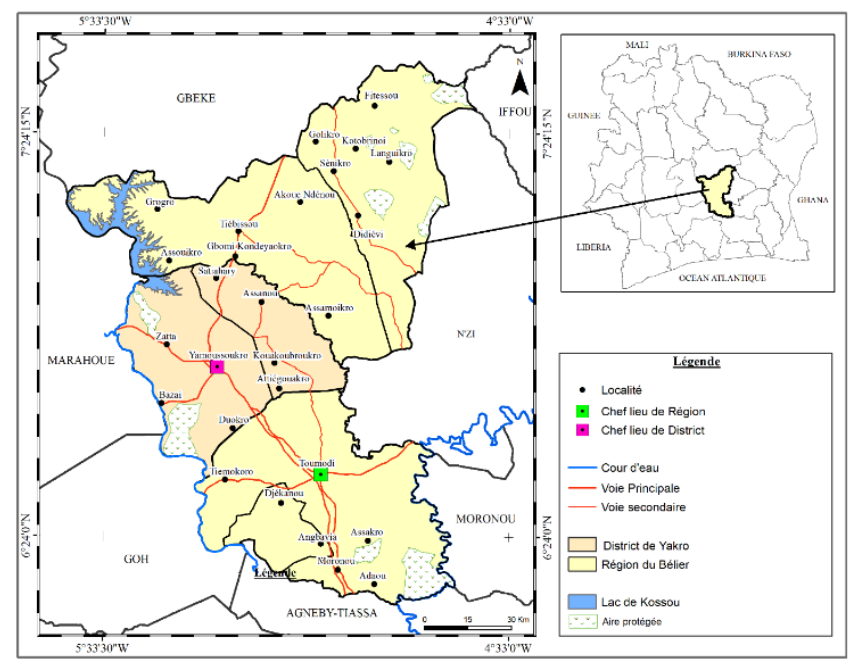

Fig. 1. Geographical location of the study area.

\section{B. Data and Materials Used}

This work was carried out using the maps of temperature, rainfall, moisture index, vegetation cover, population density of the years 2007 and 2017, maps of drainage density, slope intensity and distance to points and the 2017 schistosomal risk map of the Bélier Region and the Yamoussoukro Autonomous District. The hardware used consists of Idrisi software for makovian modelling, ArcGis 10.3 software for cartographic materialization and a Garmin GPSMAP 64

V.-C. Jofack Sokeng, Virtual University of Côte d'Ivoire, Côte d'Ivoire. (e-mail: valere.jofack@uvci.edu.ci) 
Global Positioning System (GPS) for geolocation of localities in the area of interest.

\section{Methodology}

The Markovian approach adopted in this study consists of modelling the various parameters selected above, at least those parameters that can be modified over time. The hazard (sensitivity), vulnerability and risk maps for the year 2027 were then determined by combining and weighting the different modelled parameters. In spatial analysis, the important and most frequently used special case in epidemiological risk is the Hidden Markov Model (HMM) random field [13], [14].

However, the bilharzian risk being a random phenomenon, given its propagation by outbreak and dependent on environmental and climatic conditions, can only be simulated by taking into account all the information obtained on the pathology in the past or the different areas at risk of contamination detected in the past. The determination of areas at risk of contamination in 2027 on the basis of the areas at risk determined in 2007 and 2017 can be considered as a Markovian model of order $\mathrm{K}$ where $\mathrm{K}$ corresponds to the previous instants. This process can therefore be modelled from the Markov chains of the observable Markov model.

\section{A. Markov Modelling of Bilharzian Risk Parameters}

\section{1) Modelling of climate parameters}

The different climatic parameters chosen that contribute to the expansion of schistosomiasis are temperature and rainfall. The temperature and rainfall maps of the study area for the years 2007 and 2017 having already been elaborated in the previous section, we serve as a basis or initial states in order to determine those for the year 2027. Temperature and rainfall are the most characteristic and palpable parameters in climate change analysis [15]. The fluctuations in temperature and rainfall data recorded over the years by the meteorological services testify to the constant modification of these parameters. Since the end of the 1960s, Côte d'Ivoire has experienced an aggravation of the variation of its climate. This climatic variation is particularly manifested by a modification of its pluviometric and temperature regime [16]-[19]. Global and local studies conducted by different authors have highlighted the impacts of climate variability on water resources and ecosystems. Climate variability is mainly perceived and described by the populations through the paradoxical situations of prolonged drought, floods provoking the destruction of goods and services and sometimes loss of human lives that they have experienced. The irregularity of rainfall is especially noted, leading to seasonal changes through the shortening of the rainy seasons and the lengthening of the dry seasons

\section{2) Modelling of environmental parameters}

The environmental parameters in the study that are likely to change over time and can be modelled are vegetation cover and moisture index. The modelling of vegetation cover and moisture index is justified by several studies on the dynamics of vegetation cover and hydrological behaviour [20]-[25]. Spatial organization of landscapes is an important element in locating and assessing wood resources [26]. The mapping of vegetation cover by satellite imagery using remote sensing and Geographic Information Systems, has made it possible to estimate the statistical increase or decrease in vegetation cover in several regions. In Côte d'Ivoire, the study conducted by N'Da [27] on the Marahoué National Park for its monitoring by remote sensing and Geographic Information Systems in the face of anthropic pressures, revealed the disappearance of several hectares of forest each year. This study shows that the forest area has decreased from 87,116 to 5,080 ha in 29 years (1974-2003) and is mainly due to agricultural clearing, the main cause of deforestation in this park. The deforestation of this park is the image of the Ivorian forest cover. The vegetation cover can therefore undergo changes over time.

\section{B. The steps of Markovian Modeling}

\section{1) Determination of classes or partition of states}

The determination of the classes or partition of the states is necessary for the determination of the transition matrix and is only possible after a reclassification of these states. The reclassification is done with the "RECLASS" tool of the "Database Query" module of "Gis Analysis" of the IDRISI 17.0 software. Each state was reclassified into four equivalence intervals and recorded in Table I.

\begin{tabular}{ccc} 
TABLE I: EQUIVALENCE CLASSES AND INTENSITY LEVELS \\
\hline Class & Interval & Intensity level \\
\hline 1 & $0-63$ & Very low \\
2 & $64-127$ & Low \\
3 & $128-190$ & Medium \\
4 & $191-255$ & High \\
\hline
\end{tabular}

For each parameter, two reclassified images of the years 2007 and 2017 are obtained. These two recalcified images will be used to determine the transition matrix between the two states.

\section{2) Determination of the transition matrix}

The passage from one state to another corresponds to a matrix called "transition matrix". Since the states are 10 years apart, we speak of a transition matrix with $\mathrm{k}$ steps where $\mathrm{k}$ here takes the value 10 . This matrix is determined automatically in the software (IDRISI 17.0) using the "Markov" tool in the "Environmental/Simulation models" module of the "Modeling" tab. The matrix obtained is a square matrix. Matrices with equal numbers of rows and columns are called square matrices. The number of rows and columns is the order of the matrix. Thus, it is a square matrix of order 4 according to the classes constituted above. The determination of the matrix in the "Markov" tool takes into account the initial image, that of 2007 (first land cover image); the second image, that of 2017 (second land cover image), the number of periods between the first and the second image and the number of projection years from the second image.

\section{3) Determination of states by 2027}

The determination of the states by 2027 is a model. It is a prediction of the various parameters and areas at risk of contamination in 2027. This projection was carried out using the Markov model observable by means of Markov chains. The "CA_MARKOV" tool in the "Environmental/Simulation models" module of the 
"Modeling" tab is used to make this projection. It is based on the states of the year 2017 (Basis land cover image), the transition matrix, the transition area (Markov transition areas file) and the projection year (10 years). For each modelled parameter, a rasterized image in RTS (Royal TS) format is obtained.

\section{4) Risk map for 2027}

The schistosome risk map for the year 2027 is the result of crossing the vulnerability and sensitivity maps for the year 2027 by multi-criteria analysis of the different parameters contributing to the expansion of schistosomes, projected to the year 2027. This map is obtained by weighting according to Saaty's multi-criteria ranking process (AHP).

The risk map equation is translated by the expression:

$$
\text { Risk map }=[\text { Hazard map } \mathrm{x} \text { Vulnerability map }]
$$

and can be calculated in ArcMap software by the "raster calculetor" tool according to the expression:

$$
[(0.03 \times \mathrm{PT})+(0.06 \times \mathrm{TS})+(0.13 \times \mathrm{PL})+(0.26 \times \mathrm{IH})+
$$$$
(0.51 \times \mathrm{DD})] \times[(0.08 \times \mathrm{CV})+(0.19 \times \mathrm{DE})+(0.73 \times \mathrm{DP})]
$$

\section{5) Vectorization and area calculation}

The 2027 risk map and the 2017 risk map are converted to Tiff (Tagged Image File Format) and reopened in arcGis 10.3.1. The "Raster to polygon" tool is used to vectorize the image. Vectorization is the transformation or change from Tiff (Tagged Image File Format) to shapefile (shp) format. The image is then transformed into a shapefile according to the different classes defined and according to the delimited areas. In ArcMap 10.3.1, the different classes are selected and combined into a single layer using the "Merge" tool in the "Editor" module. The "Calculate Geometry" tool is used to generate the areas occupied by each class or risk level.

\section{RESUlTS}

\section{A. 2017 Schistosomian Risk Map}

The map below (Fig. 3) shows the areas at risk of schistosomal contamination in 2017. It was developed from environmental, climatic, and demographic data for the region in 2017. There is a generalized risk throughout the region, however the western and southern parts of the region remain the most important areas in the risk of schistosomiasis contamination. The northern areas are also at high risk in several places.

\section{B. Sensitivity Map (Hazard) for the Year 2027}

The projection of the different parameters mentioned above has made it possible to draw up the hazard map for the year 2027. Fig. 4 shows the level of sensitivity of the region in 2027. High sensitivity levels are found in the southern part of the region but are gaining ground in the northern half. Several locations will become quite sensitive to schistosomal contamination over time. Increasing climatic parameters such as temperature and rainfall will lead to an evolution of the degree of sensitivity

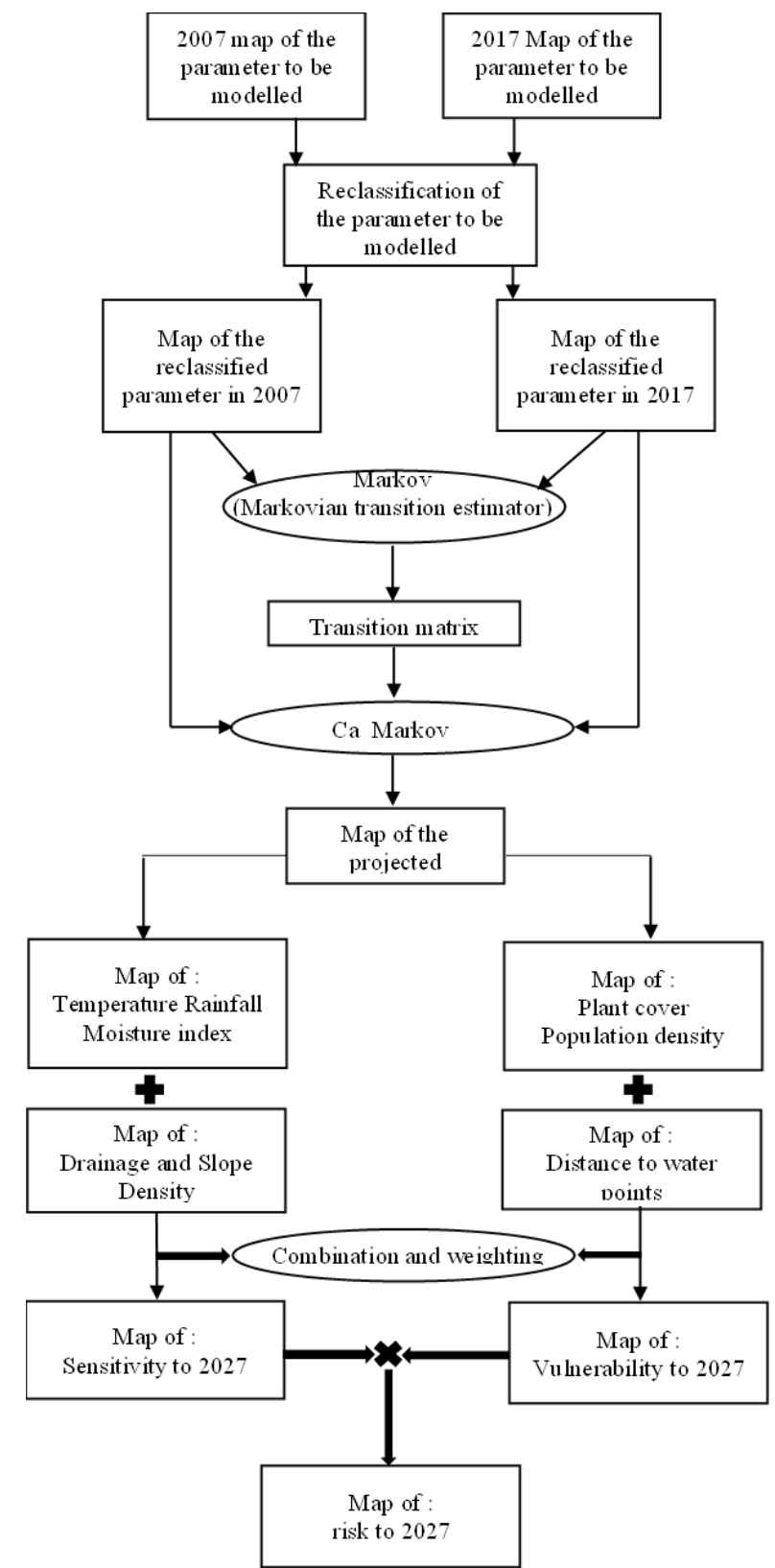

Fig. 2. Flow chart for the production of the predictive risk map for the year 2027.

\section{Vulnerability Map to 2027}

By weighting and combining the maps of vegetation cover, distance to water points and projected population density in 2027, it was possible to draw up the vulnerability map to infection (Fig. 5) by 2027. The high and medium level of vulnerability will be present in the south and in the west, especially along the Bandama River and around water points. The level of vulnerability will increase over time and gain more space, if climatic and environmental conditions remain as they are.

\section{Risk Map for 2027}

The combination of the hazard layers and the 2027 vulnerability resulted in the 2027 risk map (Figure 6). It shows a generalized risk level over the whole region. The high risk level is present in both the south and the north. The department of Yamoussoukro still predominates over the other departments and the southern half of the region is the most favourable area for the development of schistosomiasis. Several outbreaks are expected to occur in the North. 


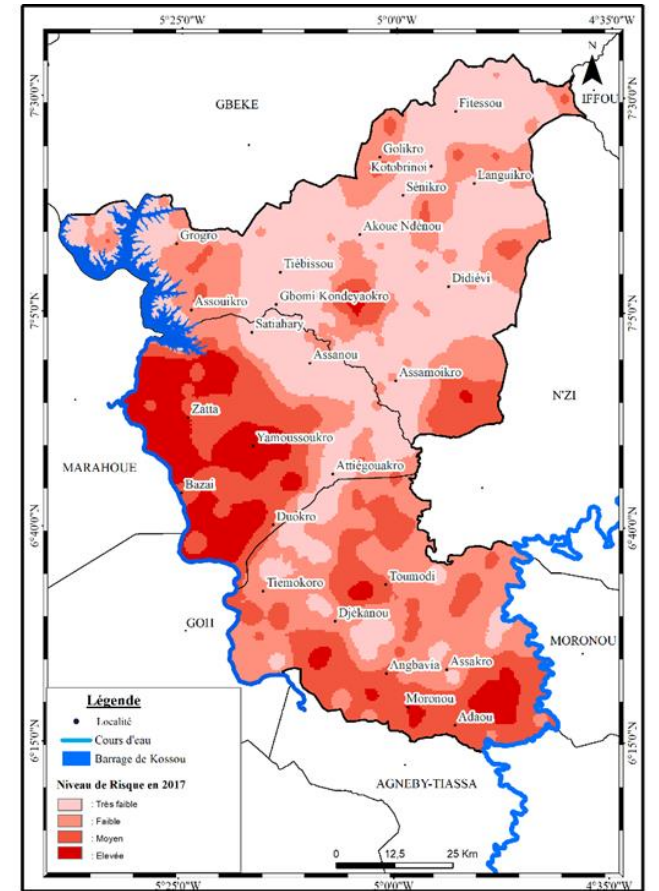

Fig. 3. Distribution of the level of risk of Schistosomiasis contamination in 2017.

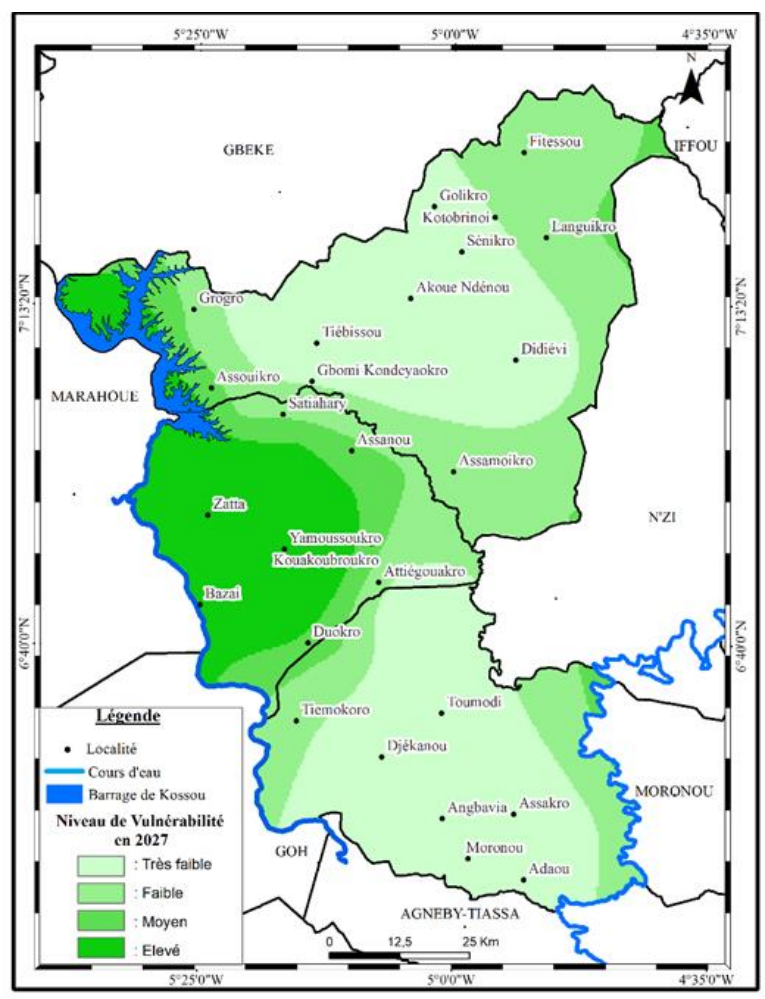

Fig. 5. Distribution of the level of vulnerability by 2027

\section{E. Statistical Evolution of Risk Levels from 2017 to 2027}

The graphs in Fig. 7 and Table II describe the surface and statistical evolution of the contamination risk levels for the years 2017 and 2027. An increase in the surface area occupied by the high intensity risk level can be observed over the decade. From $1523 \mathrm{~km}^{2}$ in 2017 , this level will occupy 2054 $\mathrm{km}^{2}$ in 2027 , i.e., $17 \%$ and $23 \%$ of the total area of the region respectively. The medium intensity risk level will possibly decrease in 2027. Thus, this level of intensity will go from $1378 \mathrm{~km}^{2}$ in 2017 to $1335 \mathrm{~km}^{2}$ in 2027 . The low and very low intensity levels are quite important in terms of surface

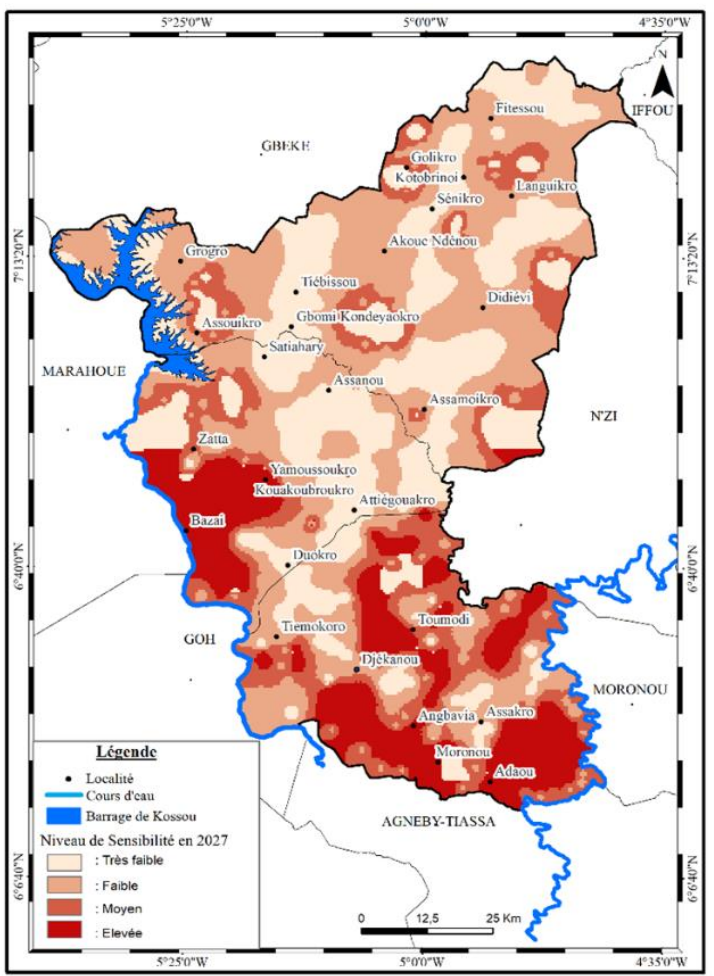

Fig. 4. Distribution of sensitivity level by 2027 .

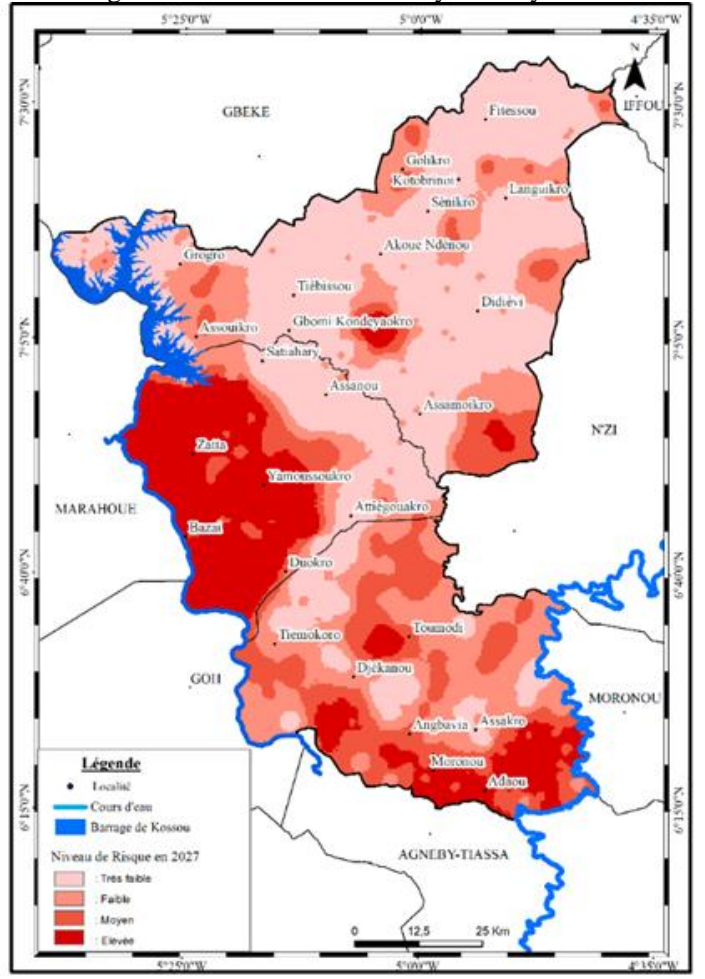

Fig. 6. Distribution of risk level by 2027.

occupation but will decrease by 2027 . From $67 \%$ in 2017 , these two levels will cumulatively occupy $62 \%$ of the total area of the region in 2027 . From the statistics presented in Fig. 7 and Table II, it can be deduced that the high-risk areas are increasing over the years and gaining space. Medium risk areas will become high risk areas. Low and very low intensity areas will gradually increase in intensity. Medium and even high intensity outbreaks will emerge over time in areas that were previously declared as no major risk. 
TABLE II: INTENSITY LEVEL AND STATISTICS OF SCHOTOSOMAL RISK IN 2017 AND 2027

\begin{tabular}{clcccc}
\hline \multirow{2}{*}{ Class } & \multirow{2}{*}{ Intensity level } & \multicolumn{2}{c}{2017} & \multicolumn{2}{c}{2027} \\
\cline { 3 - 5 } & & Area & $\%$ & Area & $\%$ \\
\hline 1 & Very low & 3717 & 42 & 3303 & 38 \\
2 & Low & 2226 & 25 & 2152 & 24 \\
3 & Medium & 1378 & 16 & 1335 & 15 \\
4 & High & 1523 & 17 & 2054 & 23 \\
\hline
\end{tabular}

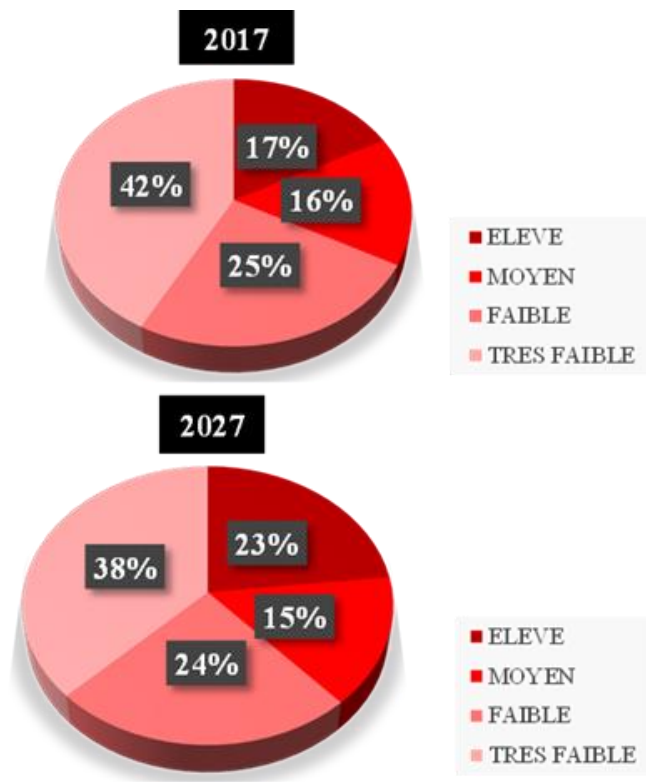

Fig. 7. Graph of the evolutionary state of the schistosomiasis risk in 2017 and in 2027.

\section{F. Number of Locations by Risk Level for the Years 2017 and 2027}

In order to better identify the areas affected by the risk of contamination, 251 localities in the study area were selected, according to those who had geographical coordinates in order to situate them in their respective risk level. They cover all areas of the region and affect all departments and subprefectures. There are 63 localities in the department of Didiévi, 19 in Attiégouakro, 17 in Djékanou, 66 in Tiébissou, 51 in Toumodi and 35 in the department of Yamoussoukro. The distribution of the selected localities by level of risk makes it possible to appreciate quantitatively but also qualitatively the phenomenon studied. Any epidemiological surveillance of risk areas will be based on the selected localities.

The graph in Fig. 8 shows the evolution of schistosomiasis risk and also the number of localities within each risk intensity level. The bands in the histogram show the area occupied by each level of risk intensity and the numbers in each band represent the number of localities corresponding to that level of risk intensity. There are 38 and 58 localities in the high-risk intensity in 2017 and 2027 respectively. These figures are increasing and evolve according to the expansion of the risk. We note the entry of 20 new localities in 2027 if the climatic and environmental conditions remain unchanged. The average intensity level is 41 and 30 localities respectively over the decade. The number of localities decreases by 11 in 2027. This level of risk intensity tends to migrate towards higher intensity and will give up localities to the high risk. The localities located in the low and very low intensity levels are more numerous and decrease over time. There are 172 locations in 2017 and this number will drop to 9 locations in 2027.

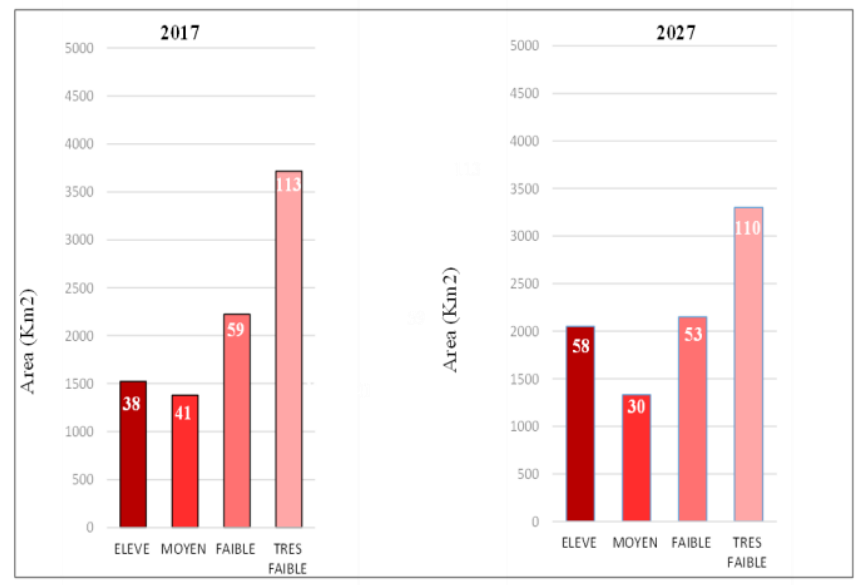

Fig. 8. Development of the number of locations by risk level.

\section{DISCUSSION}

The modeling of schistosomal risk using Markov chains is a stochastic modeling method that calculates the probability of occurrence of random phenomena. This probabilistic method was used to determine the areas at risk of contamination in our study area by 2027 . The predictive risk maps are a projection of the fate of the risk areas from the year 2017 to the year 2027. Based on the transition matrix of the decade (2007 to 2017) and the initiation vector (2017 map), the observable Markov chains have made it possible to predict the different risk intensity zones. This methodological approach necessarily involves a reclassification of the input parameters. In particular, it allowed N'guessan Bi [28], through the combined application of the observable Markov chain and the cellular automaton, to predict the land use pattern by 2020 in the department of Sinfra. Thus, in his study, semi-deciduous dense forest and bare soil will lose space to degraded forest, cultivated areas and logging areas. This progression is similar to our results where high and medium risk intensity areas will progressively increase at the expense of low and very low risk intensity areas by 2027 . The Markovian modelling also allowed him to predict the potential flood risk of the same department by 2020 .

The use of the Markovian approach or Markov chains in the modelling of land use dynamics, as in the field of meteorology or epidemiology, is not recent. Indeed, Abrial and Charras-Garrido [13], have developed the automatic classification of epidemiological risk mapping by means of hidden Markov chains. Raherinirina [29] proposed a Markovian approach to inference and modelling of agrarian dynamics of use of plots located at the edge of the forest corridor linking Ranomafana and Andringitra national parks in Madagascar.

\section{CONCLUSION}

Modelling using observable Markov chains is a methodological approach whose principles and rules have been applied in several research projects in various fields, 
including the determination of areas at risk of schistosomiasis contamination by 2027 in the Bélier region and the Yamoussoukro district. It has allowed us to know the future trends in terms of zones suitable for epidemiological surveillance and the localities that would be concerned. However, these trends could be modified if environmental conditions are to some extent affected by climate change.

\section{REFERENCES}

[1] Orsot N. M. Bilharziose et géohelminthiases dans les régions sanitaires des zones Centres et Est de la Côte d'Ivoire; dynamique des foyers de bilharziose, Thèse de doctorat de l'Université Félix Houphouët Boigny, 2019, 133p.

[2] OMS. Schistosomiase et géohelminthiases: nombre de personnes traitées en 2018. Relevé épidémiologique hebdomadaire, 2019, 94(50): 601-612.

[3] Ly B., Yaro A. S., Sodio B., Sacko M. Persistance de la schistosomiase urinaire en zones endémiques soumises aux traitements de masse répétés au Mali. Int. J. Biol. Chem. Sci. 13(1), February 2019, pp. 369381.

[4] OMS. Schistosomiase et géohelminthiases : nombre de personnes traitées dans le monde. Relevé épidémiologique hebdomadaire, 2016;91 (49/50): 585-600.

[5] Y. Yapi. Situation épidémiologique du schistosome intestinale à Schistosoma mansoni en zone humide de Côte d'Ivoire (région de Man). Thèse de Doctorat 3ème cycle, sciences naturelles, Faculté des Sciences et Techniques, Université d'Abidjan, Côte d'Ivoire, 1988, $157 \mathrm{p}$.

[6] N'goran K.E. Environnement et transmission des schistosomoses à «oeuf éperon terminal» en Côte d'Ivoire. Afrique de l'ouest. Thèse de Doctorat Université de Cocody. 1998, 199p.

[7] Utzinger, E. K. N'goran, Y. A. Ossey, M. Traore, K. L. Lohourignon, A. Allangba, L. A. Ahiba, M. Tanner, C. Lengeler. Rapid screening for schistosoma mansoni in western Côte d'Ivoire using a simple school questionnaire. Bulletin of the world health organization, 2000;78 (3): 389-398.

[8] N'guessan A.N. La lutte contre les schistosomoses en Côte d'Ivoire : facteurs de complexité épidémiologie et contraintes opérationnelles à la lutte. Thèse de Doctorat de l'Université d'Abidjan, Côte d'Ivoire, 2003, 127p.

[9] Cecchi P., Balde, S. Yapi Y. G. Mollusques hôtes intermédiaires de bilharzioses dans les petits barrages. In: Cecchi P. (Ed.), Leveque C. (Pref.), Aubertin C. (Pref.). L'eau en partage: les petits barrages de Côte d'Ivoire. Paris: IRD, 2007, pp. 175-189.

[10] N'guessan N. A., Acka C. A., Utzinger J., N'goran E. K. Identification des régions à haut risque de schistosomoses en Côte d'Ivoire. Bulletin de la Société de pathologie exotique ISSN 0037-9085 CODEN BSPEAM. 2007;100(2): 119-123.

[11] Kouame A.K.D. Facteurs de répartition et essai de modélisation des bilharzioses et des géohelminthiases par des techniques de télédétection et système d'information géographique pour un développement durable dans la région de l'Agnéby. Thèse de doctorat unique, Université Felix HOUPHOUËT BOIGNY d'Abidjan, 2010, 144 p.

[12] N'guessan A.N., Garba A. Orsot N. M, N'goran K. E. Evaluation de la morbidité échographique de la bilharziose urinaire chez les écoliers de 6 localités autour du barrage de Taabo (Côte d'Ivoire). International Journal of Innovation and Applied Studies ISSN 2028-9324, 2014;9(1): 307-316.

[13] Abrial D. et Charras-Garrido M. Classification automatique par champs de Markov cachés pour la cartographie du risque en épidémiologie. 41èmes Journées de Statistique, SFdS, Bordeaux, 2009, Bordeaux, France, France. 2009. <inria-00386630>, 2009, 6p.

[14] Aziz L. Champs aléatoires de Markov cachés pour la cartographie du risque en épidémiologie. Thèse de doctorat, Université de Grenoble, 2011, 179p.

[15] Barrat J. M. Changements climatiques en Afrique de l'Ouest et conséquences sur les Eaux Souterraines. Gestion intégrée et concertée des ressources en eau des systèmes aquifères d'Iullemeden, de Taoudemi/Tamezrouft et du fleuves Niger-GICRESAIT. Faculté Africaine de l'eau. Rapport OSS- GICRESAIT n ${ }^{\circ} 13,2012,41 \mathrm{p}$.

[16] Bigot S. Variabilité climatique, interaction et modifications environnementales. L'exemple de la Côte d'Ivoire. Document de synthèse des activités scientifiques rédigé dans le cadre d'une habilitation à diriger des recherches. Centre national de la recherche scientifique. Université des sciences et techniques de Lilles, 2004 399p.

[17] Yao A. B., Goula B. T. A., Kouadio Z. A., Kouakou K. E., Kane A., Sambou S. Analyse de la variabilité climatique et quantification des ressources en eau en zone tropicale humide: cas du bassin versant de la Lobo au centre-ouest de la côte d'ivoire. Rev. Ivoir. Sci. Technol., 2012;19:136-157, ISSN 1813-3290.

[18] Fossou R. M. N., Soro N., Traore V. B., Lasm T., Sambou S., Soro T., Orou R. K., Cisse M. T., Kane A. Variabilité climatique et son incidence sur les ressources en eaux de surface: cas des stations de Bocanda et de Dimbokro, Centre-Est de la Côte d'Ivoire en Afrique de l'Ouest. Afrique SCIENCE 2014;10(4):118-134.

[19] Boko-K., Gueladio C., Brama K., Dedy S.,. Variabilité climatique et changements dans l'environnement à Korhogo en Côte D'ivoire : mythes ou réalité ? European Scientific Journal February 2016 edition, 2016;12(5): 19. ISSN: 1857 - 7881 (Print) e - ISSN 1857- 7431.

[20] Andréassian V., Tangara M., Muraz J. Évaluer l'impact de l'évolution du couvert forestier sur le comportement hydrologique des bassins versants : méthodologie et premiers résultats fondés sur les données de l'IFN, 2001, pp. 475-480.

[21] Abdelbaki A. Utilisation des SIG et télédétection dans l'étude de la dynamique du couvert végétal dans le sous bassin versant de oued Bouguedfine (Wilaya de Chlef). Mémoire de magister en biologie, Université Hassiba BEN BOUALI CHLEF de d'Algérie. 2012, 110p.

[22] Anzoumana S. S. Suivi du couvert végétal en milieu savanicole et ses impacts climatiques par l'utilisation de la télédétection et SIG: cas de la préfecture de l'Oti (nord Togo entre 1987-2015). Mémoire de Master, Université Félix Houphouët Boigny, 2015, 87p

[23] Tankoano B., Hien M., Dibi N.H., Sanon Z., Akpa Y.L., Jofack Sokeng V-C., Somda I. Cartographie de la dynamique du couvert végétal du Parc National des Deux Balé à l'Ouest du Burkina Faso. International Journal of Innovation and Applied Studies ISSN 2028-9324 2016;16(4): 837-846

[24] Etene C. G., Dossou-Yovo E., Sintondji L. O., Vissin E. W. Impacts des changements climatiques et de la dynamique du couvert végétal sur les ressources en eau dans le bassin de l'Okpara à l'exutoire de Kaboua à l'horizon 2025. Journal de la Recherche Scientifique de l'Université de Lomé (Togo). Publ. No5, ISSN: 1727-8651, 2017: 129-144.

[25] Gbedahi O. L. C., Biaou S. S. H., Mama A., Gouwakinnou G. N., Yorou N. S. Dynamique du couvert végétal à Bassila au nord Bénin pendant et après la mise en œuvre d'un projet d'aménagement forestier. Int. J. Biol. Chem. Sci., 2019; 13(1):311-324.

[26] Boulogne M., Pennec, A., Dubiez E., Gigaud M., Péroches A., Lavialle J., Rerolles J., Proces P., Peltier R., Marien J-N., Gond V. Dynamique d'évolution du couvert végétal et des stocks de carbone dans le bassin d'approvisionnement de la ville de Kinshasa. Quand la ville mange la forêt: Les défis du bois-énergie en Afrique centrale, Versailles, Ed. Quae, 2013, pp. 45-59.

[27] N'da D. H. Étude et suivi par télédétection et système d'informations géographiques d'une aire protégée soumise aux pressions anthropiques : cas du parc national de la Marahoué. Thèse de doctorat. Université Félix Houphouet Boigny. 2007, 181p.

[28] N'guessan Bi V. H., Modélisation markovienne du champ de précipitations et du mode d'occupation du sol pour une prévision du risque d'inondation à l'aide de la télédétection et des systèmes d'informations géographiques (SIG) : cas du département de Sinfra (centre-ouest de la Côte d'Ivoire). Thèse de doctorat, Université de Cocody, Abidjan, 2014, 229p.

[29] Raherinirina F. A. Modélisation markovienne des dynamiques d'usage des sols Cas des parcelles situées sur le bord du corridor forestier Ranomafana-Andringitra. Thèse de doctorat. Université de Fianarantsoa. 2013, 146p. 